Determination of the Species of Tephritidae family (Diptera) on Cherry Orchards in Adana Province and Surroundings in Turkey

\author{
Burcu ÖZBEK ÇATAL ${ }^{1}$ (D) , Asime Filiz ÇALIŞKAN KEÇE2 ${ }^{(D)}$, Mehmet Rufat ULUSOY ${ }^{3}$ (D) \\ ${ }^{1}$ Çukurova University, Pozantı Vocational School, Department of Plant and Animal Production, 01470, Pozantı, Adana, \\ ${ }^{2,3}$ Çukurova University, Department of Plant Protection, Faculty of Agriculture, 01330, Balcalı, Adana \\ ${ }^{1}$ https://orcid.org/0000-0003-0029-6190, ${ }^{2}$ https://orcid.org/0000-0002-9330-1958, ${ }^{3}$ https://orcid.org/0000-0001-6610-1398 \\ $\varangle$ : bozbek@cu.edu.tr
}

\section{ABSTRACT}

This study was conducted to determine the species belonging to the Tephritidae (Diptera) family in the cherry cultivations in Adana province and surroundings. Samples were collected with periodic and non-periodical survey from host plants in cherry orchards during 2015-2018. In this study, nine species belonging to Tephritidae family were found. These species were; Rhagoletis cerasi (Linnaeus, 1758), Ceratitis capitata (Wiedemann, 1824), Rhagoletis batava (Hering, 1958), Carpomya schineri (Loew, 1856), Tephritis nigricauda (Loew, 1856), Tephritis fallax (Loew, 1844), Tephritis dioscurea (Loew, 1856), Tephritis hurvitzi (Freidberg, 1981), Tephritis divisa (Rondani, 1871).

\section{Short Communication}

$\begin{array}{ll}\text { Article History } \\ \text { Received } \quad: 28.01 .2018 \\ \text { Accepted } & : 28.02 .2019\end{array}$

\section{Keywords}

Cherry

Tephritidae

Diptera

Adana

Turkey

\title{
Adana İli ve Çevresi Kiraz Bahçelerinde Tephritidae (Diptera) Familyası Türlerinin Belirlenmesi
}

\section{ÖZET}

$\mathrm{Bu}$ çalışma, Kiraz yetiştiriciliği yapılan Adana ili ve çevresinde Tephritidae (Diptera) familyasına bağlı türlerin belirlenmesi amaciyla yürütülmüştür. Örnekler 2015 - 2018 yılları boyunca kiraz bahçesinde bulunan tüm konukçu bitkilerden periyodik ve periyodik olmayan arazi çıkışları ile toplanmıştır. Çalışmada, Tephritidae familyasına ait dokuz tür tespit edilmiştir. Bu türler; Rhagoletis cerasi (Linnaeus, 1758), Ceratitis capitata (Wiedemann, 1824), Rhagoletis batava (Hering, 1958), Carpomya schineri (Loew, 1856), Tephritis nigricauda (Loew, 1856), Tephritis fallax (Loew, 1844), Tephritis dioscurea (Loew, 1856), Tephritis hurvitzi (Freidberg, 1981) ve Tephritis divisa (Rondani, 1871)' dir.

\section{Kisa Not}

\section{Makale Tarihçesi}

Geliş Tarihi : 28.01 .2018

Kabul Tarihi : 28.02 .2019

Anahtar Kelimeler
Kiraz
Tephritidae
Diptera
Adana
Türkiye

To Cite : Özbek Çatal B, Calışkan Keçe AS, Ulusoy MR 2019. Adana İli ve Cevresi Kiraz Bahçelerinde Tephritidae (Diptera) Familyası Türlerinin Belirlenmesi. KSÜ Tarım ve Doğa Derg 22(3): 492-497. DOI: 10.18016/ksutarimdoga.v22i44724.518676

\section{INTRODUCTION}

The fruit flies (Tephritidae) are one of the most economically important pests and largest families of Acalyptrate Diptera with approximately 500 genera, and about 4500 species, specifically, in tropics and subtropics. Most species are phytophagous. Some of them are harmful such as Rhagoletis cerasi, Ceratitis capitata etc. (White and Elson-Harris, 1992). In Palaearctic Region, and especially in Europe, this family is represented by a few dozens of fruit-feeding species, including the medfly $C$. capitata, the cherry fruit fly $R$. cerasi, but the vast majority of Palearctic species, which belong to the subfamily Tephritinae, feed in flower heads and stems (often forming galls) on plants of the family Asteraceae (Korneyev, 2003). According to Norrbom et al. (1999) and Korneyev and Dirlbek (2000), Tephritis Latreille is the sixth largest genus of Tephritidae with about 170 species, and the third largest genus of the subfamily of Tephritinae. The most of the species belonging to genus are Palearctic.

When economically evaluated, fruit flies damage the vegetables and fruits directly, causing quarantine areas under invasion, and having required such fruits to be exposed to quarantine treatment before exportation.

The identification of species belonging to the Tephritidae family, as in other insect groups, is made during the adult stage. The Tephritidae family in Adana has been published in some Diptera studies (Becker, 1913; Séguy, 1930, 1934, 1941, 1949, 1953). Various studies on the Diptera fauna in Turkey were also performed by Giray (1969, 1979), Hayat and 
Özbek (1994), Civelek et al. (2000), Clkman and Uygun (2003), Kütük and Özgür (2003), Civelek (2004), Kılıç (2004). Yaran and Kütük (2016) has been reported the number of fruit flies species as 160 . In recent studies, the insect fauna of Turkey in cherry orchards has been investigated (Ulu et al., 1995; Özbek et al., 1996; Özder, 1999; Ulusoy et al., 1999). R. cerasi is a common and main pest in cherry. The aim of this study was to provide some data for Tephritidae fauna and also the fauna of cherry orchards in Turkey.

\section{MATERIAL and METHODS}

The samples were collected from cherry orchards in Adana province and its surroundings during 20152018. The adult flies of Tephritidae were collected by insect traps and nets. Traps were set on the trees in the orchards and checked once a week. The insect nets were swung randomly to the adult species seen on the host plants and the insects were collected. All samples were deposited in the Nedim Uygun Biological Control Laboratory in Plant Protection Department of Agriculture Faculty, Çukurova University, Adana, Turkey. The insects were identified by the authors and Associate Professor Dr. Murat Kütük (Gaziantep University, Gaziantep, Turkey).

\section{RESULTS and DISCUSSION}

In total, 9 species belonging to 4 genera in 3 subfamilies (Dacinae, Tephritinae and Trypetinae) were determined from Adana provinces. In this paper, the distribution and host plants species of all materials examined were presented and the species were listed in alphabetical order.

\section{Rhagoletis cerasi (Linnaeus) (Figure 1a)}

Material examined: Adana: Aladağ, Meydan, 11.V.2017, 2우, Aladağ, Değirmencik, 07.VI.2018, 3우오, Aladağ, Yeniköy, 07.VI.2018, 1ㅇ, Feke, 20.V.2017, 2우, Karaisalı, Hacıkırı, 03.VI.2016, 2 우우, Karaisalı, Kızıldağ, 01.VI.2018, 1, Pozantı, Alpu, 17.V.2016, 5우오, Pozantı, Alpu, 22.V.2017, 7우우, $2 \AA^{\lambda} \oint^{\lambda}$, Pozantı, Findıklı, 04.VI.2017, 2우, Pozantı, Ömerli, 02.VI.2017, 5오, Saimbeyli, Merkez, 20.V.2017, 3오오, Saimbeyli, Merkez, 29.VI.2018, 2우, Saimbeyli, Gürleşen, 29.VI.2018, क, Saimbeyli, Obruk, 29.VI.2018, 1ㅇ, Tufanbeyli, 4.VII.2017, 1ㅇ, Tufanbeyli, 29.VI.2018, 3ㅇ; Mersin: Çamliyayla, Fakılar, 16.VI.2016, 5우, Tarsus, Kurtçukuru, 16.VI.2016, 3우; Niğde: Ulukışla, Darboğaz, 27.V.2015, 3우이, 1ð, Ulukışla, Darboğaz, 08.VI.2016,

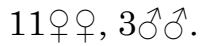

Host: Prunus. avium L., P. mahaleb L., P. cerasus L., $P$. serotina Ehrh (Rosaceae) and Lonicera tatarica L., L. xylosteum L. (Caprifoliaceae) (Hendel, 1927; Afshar, 1937; White and Elson-Harris, 1992; Merz, 1994; Ulusoy et al., 1999).
Distrubition in the world: Canada, Europe, Georgia, Iran, Kazakhstan, Russia, Turkey (Afshar, 1937; Norrbom et al., 1999; Ulusoy et al., 1999; Mohamadzade Namin and Rasoulian, 2009; EPPO, 2017).

Remarks: $R$. cerasi is the most serious pest in cherry orchards in Turkey, causing fruit damage and yield losses. The adult flies emerge from the soil in May to June in Adana. Occurs on cherries and honeysuckles in Turkey. In this study, host of the species is P. avium. When the flies are uncontrolled, cherry trees can be infested $100 \%$.

\section{Ceratitis capitata (Wiedemann) (Figure 1b)}

Material examined: Adana: Aladağ, Meydan, 11.V.2017, 1우, Aladağ, Değirmencik, 07.VI.2018, 2 우우, Pozantı, Alpu, 20.VII.2016, 2우, Pozantı, Alpu,

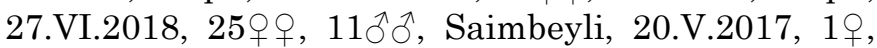
Saimbeyli, Merkez, 29.VI.2018, 1오․ Saimbeyli, Obruk, 29.VI.2018, 1, Tufanbeyli, 04.VII.2017, 2우, Tufanbeyli, 29.VI.2018, 1 ․

Hosts: Larvae on $P$. avium, P. persica, Pyrus communis L. and Malus domestica Borkh. (Rosaceae). More than 250 plant types.

Distrubition in the world: Africa, Asia, Europe, Central America- Caribbean, South and North America, Spain, Oceania, Turkey (Enkerlin et al., 1989; Fimiani, 1989; Norrbom et al.,1999; EPPO, 2014).

Remarks: This pest began to be seen in traps at the beginning of July at the end of June within the study area (especially above altitudes of $1200 \mathrm{~m}$ ) and it has been detected the fruit on the tree.

\section{Rhagoletis batava (Hering) (Figure 1c)}

Material examined: Adana: Pozantı, Alpu, 08.VI.2017, 2웅, Pozantı, Alpu, 04. VII.2017, 1우, Pozantı, Alpu, 19.VII.2018, 4 우우.

Hosts: Hippophae rhamnoides L., Rhamnaceae sp. (Richter, 1970; Baugnée, 2006) and P. avium.

Distrubition in the world: Armenia, Belgium, Belarus, Finland, Estonia, Germany, Hungary, Italy, Kyrgyzstan, Latvia, Lithuania, Poland, Russian Federation (European division), Sweden, Switzerland, Spain, The Netherlands and Turkey. Non-European: North-Central Caucasus; Russian Federation and South Siberian mountains: Altai, Tuva (Pakyürek, 2006; Koçak and Kemal, 2013; EPPO, 2017; Stalažs and Balalaikins, 2017).

Remarks: $R$. batava is an economically important pest and aggressive of $H$. rhamnoides in Europe. But, It has been reported that these flies can develop also on several other trees and bushes in natural vegetation, i.e. Cerasus mahaleb and Lonicera spp., etc. (Anonymous, 2018). 
Carpomya schineri (Loew) (Figure 1d)

Material examined: Adana: Pozantı, Alpu, 14.VI.2016, 1오, Pozant1, Alpu, 25.VII.2018, 1 ㅇ.

Hosts: P. avium, Rosa beggerana Schrenk, $R$. canina L., $R$. damascena Mill., $R$. gallica L., $R$. pulverulenta M.B., Rosa kokanica (Regel) Regel et Juz., $R$. rubiginosa L., $R$. spinosissima L., $R$. rugosa Thunb., $R$. villosa L., (Rosaceae) (Hendel, 1927; Kandybina, 1977; Freidberg and Kugler, 1989; Smith and Bush, 1999).

Distrubition in the world: Austria, Bulgaria, Germany, Hungary, Italy, Northern Africa Spain, Slovakia, Switzerland, Spanish Mainland, Turkey, Ukraine
(White and Elson-Harris, 1992; Merz, 1994; Korneyev, 2003; Pakyürek, 2006; Koçak and Kemal, 2013).

Remarks: Yellow sticky traps with ammonia capsules (Trece-Pherocon ${ }^{\circledR}$ AM) traps set out to detect the cherry fruit fly $(R$. cerasi) on $P$. avium, single specimens of $C$. schineri were recorded. But the damage on $C$. schineri was not detected. It has been reported that $C$. schineri has damaged only rose berries (Papp, 1994; Surányi and Haltrich, 2006; Tuba, 2009). Studying and observations should be continued on cherries whether it does any damage.

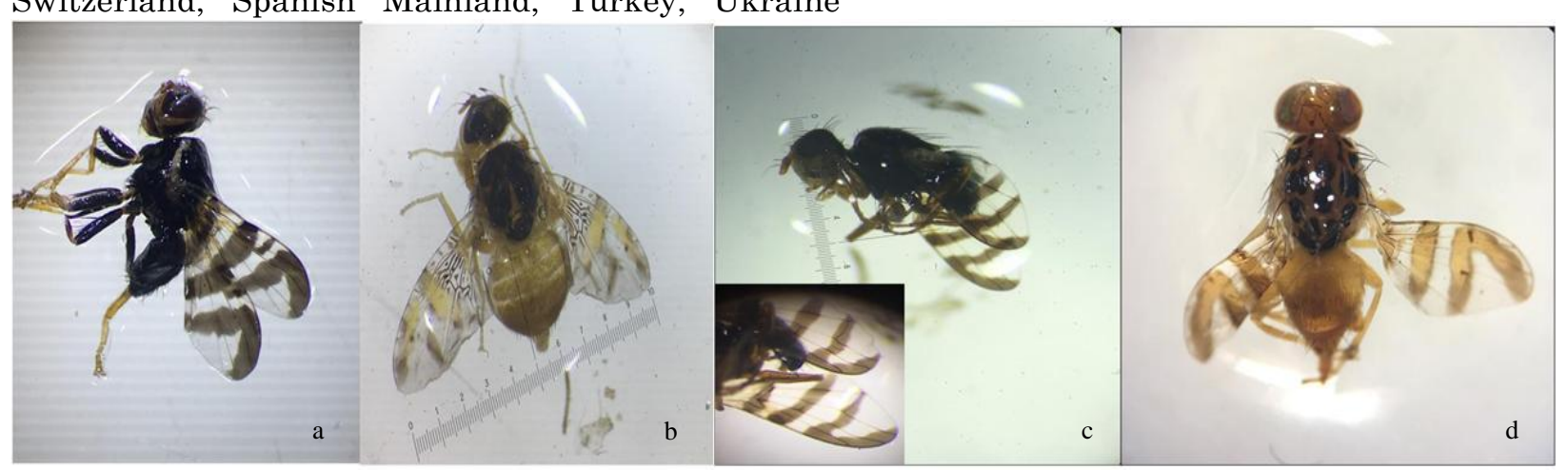

Figure 1. General view of adult fly: (a) Rhagoletis cerasi, (b) Ceratitis capitata, (c) Rhagoletis batava, (d) Carpomya schineri (Photos: BÖÇ).

\section{Tephritis nigricauda (Loew) (Figure 2a)}

Material examined: Adana: Pozantı, Alpu, 31.V.2017, 3 우아.

Hosts: Achillea millefolium L., A. ptarmica L., Anthemis arvensis L. (Asteraceae) (Merz, 1994).

Distrubition in the world: Afghanistan, Austria, Estonia, Italy, Latvia, Lithuania, Moldova, Russia, Syria, Switzerland, Ukraine, and Turkey (Foote, 1984; Merz, 1994; Thompson, 1998; Kütük and Özgür, 2003).

Remarks: This species was first recorded from Turkey (Kütük and Özgür, 2003) and was described on Asteraceae. In the previous studies has not been recorded any damage on cherry trees. This species were collected on $P$. avium but the damage on $T$. fallax was not detected.

\section{Tephritis fallax (Loew) (Figure 2b)}

Material examined: Adana: Pozantı, Alpu, 08.VI.2017, 1 ㅇ․

Host: Leontodon hispidus L. (Merz, 1994).

Distrubition in the world: Estonia, Germany, Kazakhstan, Latvia, Lithuania, Poland, Russia, Romania, Sweden, Switzerland, Turkey, and Ukraine (Foote, 1984; Merz, 1994; Thompson, 1998; Özgür and Kütük, 2003).

Remarks: This species were collected on $P$. avium but was not detected any damage on $T$. fallax.

\section{Tephritis dioscurea (Loew) (Figure 2c)}

Material examined: Adana: Pozantı, Alpu, 08.VI.2017, 1 우.

Hosts: Artemisia absinthium L., A. crithmifolia L., A. millefolium, Chrysanthemum corymbosum L. (Asteraceae) (Hendel, 1927; Merz, 1994; Kütük, 2005). Distrubition in the world: Armenia, Austria, Azerbaijan, Estonia, Far East, France, Germany, Georgia, Hungary, Kazakhistan, Latvia, Lithuania, Moldova, Russia, Sweden, Switzerland, Turkey and Ukraine (Hendel, 1927; Foote, 1984; Merz, 1994; Thompson, 1998; Kütük, 2005).

Remarks: This species was first recorded from Turkey by Kütük (2005). It has not been detected on cherry as pest, but it has been reported by researchers who indicated that the larvae of $T$. dioscurea damaged the flower heads of Asteraceae.

\section{Tephritis hurvitzi (Freidberg) (Figure 2d)}

Material examined: Adana: Pozantı, Alpu, 08.VI.2017, ㅇ.

Hosts: Scorzonera syriaca Boiss \& Blanche and Tragopogon longirostris Bisch. (Freidberg and Kugler, 1989).

Distrubition in the world: Europe, Iraq, Iran, Israel, Jordan, Lebanon, Middle Asia, Syria, and Turkey (Norrbom et al., 1999; Korneyev and Dirlbek, 2000; Kütük and Özgür, 2003; Özgür and Kütük, 2003; 
Mohamadzade Namin et al., 2010).

Remarks: Most species of Tephritis sp. develop the flower heads of Asteracae but this species in stems of Asteraceae cause the emergence of galls (Freidberg, 1984; Merz, 1994). It has not been observed any damage on cherry trees.

\section{Tephritis divisa (Rondani) (Figure 2e)}

Material examined: Adana: Pozantl, Alpu, 04.VII.2017, 2 우.
Hosts: Picris echioides L. (Asteraceae) (Merz, 1994; Kütük, 2005).

Distrubition in the world France, Greece (Crete), Italy, Israel, Switzerland, Spain, and Turkey (Merz, 1994; Thompson, 1998; Kütük, 2005).

Remarks: This species was recorded from Turkey by Kütük (2005) on $P$. echioides. The larvae of $T$. divisa develops in flower head of $P$. echioides. It has not been detected on cherry.
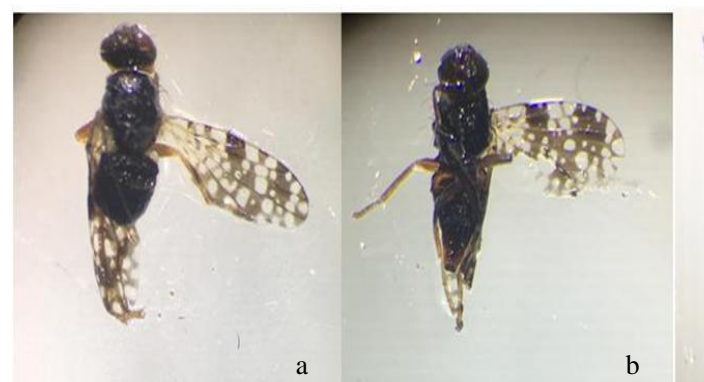

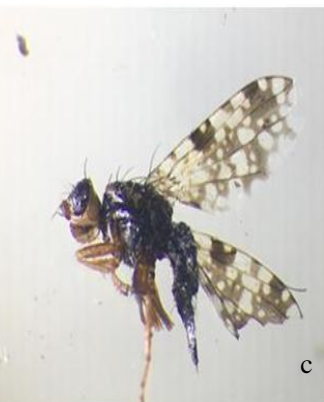

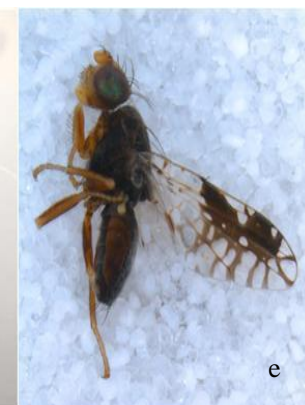

Figure 2. General view of adult fly: (a) Tephritis nigricauda, (b) Tephritis fallax, (c) Tephritis dioscurea, (d) Tephritis hurvitzi (Photos: BÖÇ), (e) Tephritis divisa (http://v3.boldsystems.org/index.php/ Taxbrowser_Taxonpage?taxid=285046).

\section{RESULTS}

As a result of this study, nine species belonging to 4 genera (Rhagoletis, Ceratitis, Carpomya and Tephritis) have been determined. According to previous studies, Tephritis Latreille is common genus with 24 species in Turkey (Kütük, 2006, 2008; Kütük et al., 2012). The results of this study have showed similarities with previous studies and the biodiversity of Adana province and surroundings in Turkey. $R$. batava from these pests is aggressive, economically important pest and a serious threat of its dispersion. It can infest several other trees i.e. Cerasus mahaleb, Lonicera spp., etc apart from the main host plant (Anonymous, 2018). More studies need to be conducted in order to have better understanding of damage status of this pest on cherry.

\section{ACKNOWLEDGMENTS}

I would like to thank to Associate Prof. Dr. Murat Kütük (Gaziantep University, Faculty of Arts and Science, Department of Biology) for the diagnosis of fly species. This study was supported by Çukurova University as scientific research project; project number FBA-2016-6528.

\section{REFERENCES}

Afshar J 1937. Harmful insects of fruit trees in Iran. Journal of Agricultural Organization, 17: 1-11.

Anonymous 2018. Sea buckthorn fly- Rhagoletis batava Hering (http://www.csalomontraps.com/ 4listbylatinname/pdffajonkentik/rhagoletisbatava2 016.pdf) (accessed on: July, 2018).

Baugnée JY 2006. Contribution à la connaissance des Tephritidae de Belgique (Diptera: Brachycera). Notes fauniques de Gembloux, 59: 63-113.

Becker T 1913. In Becker and Stein: Dipteren ause Marokko. Annuaire du Musée zoologique de l'Académie des sciences de St. Pétersbourg, 18: 6476.

Civelek HS 2004. Two new records for the Turkish Agromyzidae (Diptera) fauna. Turkish Journal of Entomology, 28(1): 15-19.

Civelek HS, Deeming JC, Önder F 2000. Some new records for Turkish leafminers (Diptera: Agromyzidae) fauna from İzmir province. Turkish Journal of Entomology, 24(1): 17-26.

Çlkman E, Uygun N 2003. The determination of leafminers (Diptera: Agromyzidae) and their parasitoids in cultivated and non-cultivated areas in Șanliurfa province, southern Turkey. Turkish Journal of Entomology, 27(4): 305-318.

Enkerlin E, Garcia L, Lopez F 1989. Mexico, Central and south America. In: Fruit Flies: Their biology, Natural Enemies and Control (Ed: A.S. Robinson; G. Hooper). Elsevier Science Publ., Amsterdam, Netherlands, 3: 83-90 pp.

EPPO 2014. PQR database. Paris, France: European and Mediterranean Plant Protection Organization. (http://www.eppo.int/DATABASES/pqr/pqr.htm) (accessed on: May 2018).

EPPO 2017. EPPO Global database (available online). Paris, France: EPPO. (https://gd.eppo.int/ 
taxon/RHAGBA/distribution) (accessed on: May 2018).

Fimiani P 1989. Mediterranean region. In: Fruit flies: their biology, natural enemies and control (Ed: Robinson AS, Hooper GH). Elsevier Science Publ, Amsterdam, Netherlands, 3: 39-50pp.

Foote RH 1984. Family Tephritidae, In: Catalogue of Palaearctic Diptera (Ed: A. Soos and L. Papp). Budapest and Elsevier Science Publishers, Amsterdam, 9: 66-149 pp.

Fridberg A 1984. "Gall Tephritidae (Diptera), 129167pp". In: Biology of Gall Insects (Ed: T.N. Ananthakrishnan), Oxford \& IBH, New Delhi, 362 pp.

Freidberg A, Kugler J 1989. Diptera: Tephritidae. Fauna Palaestina, Insecta, 4: 1-212.

Giray H 1969. Ege bölgesinde yabani otlarda bulunan Trypetidae (Diptera) türleri ile ilgili faunistik araştırmalar. Ege Üniversitesi Ziraat Fakültesi Dergisi, 6(1): 71-78.

Giray H 1979. Türkiye Trypetidae (Diptera) faunasina ait ilk liste. Türkiye Bitki Koruma Dergisi, 3: 3546.

Hayat R, Özbek H 1994. New records of robber flies (Diptera: Asilidae) for Turkish fauna. Turkish Journal of Entomology, 18(4): 241-244.

Hendel F 1927. Trypetidae. In: Die Fliegen der paläarktischen Region 5 (E. Lindner, ed.), Stuttgart: Sweizerbart, 5: 1-221pp.

Kandybina MN 1977. Larvae of fruit-infesting fruit flies (Diptera, Tephritidae). Nauka, Leningrad, Nauka, Leningrad, 114: 1-210.

Kılıç AY 2004. Bolu ili Tabanidae (Insecta: Diptera) faunası. Turkish Journal of Entomology, 28(1): 5768.

Koçak AÖ, Kemal M 2013. Tephritidae in Turkey: an evaluation of its status from various standpoints (Diptera). Centre for Entomological Studies Ankara (CESA), 84: 1-50.

Korneyev VA, Dirlbek J 2000. The fruit flies (Diptera: Tephritidae) of Syria, Jordan and Iraq. Studia Dipterologica, 7(2): 463-482.

Korneyev VA 2003. New and little-known Tephritidae (Diptera: Cyclorrhapha) from Europe. Vestnik Zoologii, 37(3): 3-12.

Kütük M 2005. Two new records of Tephritis Latreille, 1804 (Diptera: Tephritidae) from Turkey. Turkish Journal of Zoology, 29: 167-170.

Kütük M 2006. The fauna and systematics of the genus Tephritis Latreille, 1804 (Diptera: Tephritidae) with a key to the species of Tephritis in Turkey. Turkish Journal of Zoology, 30: 345-356.

Kütük M 2008. A new species of Tephritis Latreille, (Diptera: Tephritidae) from Turkey. Belgian Journal of Zoology, 138: 132-134.

Kütük M, Özgür AF 2003. Faunistical and systematical studies on the genus Tephritis
Latreille,1804 (Diptera: Tephritidae) in the South West of Turkey along with new records. Turkish Journal of Entomology, 27: 243-252.

Kütük M, Bayrak N, Hayat R 2012. A new species of Tephritis Latreille (Diptera: Tephritidae) from Turkey. Turkish Journal of Zoology, 36: 475-480.

Merz B 1994. Diptera: Tephritidae in insecta helvetica fauna. Schweizerischen Entomologischen Gesellschaft, Geneve, 10: 1-198.

Mohamadzade Namin S, Rasoulian GR 2009. Fruit flies of the genus Rhagoletis Loew (Diptera: Tephritidae) of Iran and bordering countries, with the key to species. Vestnik Zoologii, 43 (1): 81-86.

Mohamadzade Namin S, Nozari J, Najarpour A 2010. The fruit flies (Diptera: Tephritidae) in the fauna of Ardabil province, with new records for Iran. Ukrainska Entomofaunistyka, 1(3): 35-41.

Norrbom AL, Carroll LE, Thompson FC, White IM, Freidberg A 1999. Systematic database of names. Fruit fly expert identification system and systematic information database, Backhuys Publishers, The Netherlands, Myia, 9: 65-251.

Özbek H, Güçlü Ş, Hayat R 1996. Kuzeydoğu tarım bölgelerinde taş çekirdekli meyve ağaçlarında bulunan fitofag ve predatör böcek türleri. Turkish Journal of Agriculture and Forestry, 20: 267-282.

Özder N 1999. "Tekirdağ ilinde kiraz bahçelerinde bulunan doğal düşmanlar ve bunlardan yumurta parazitoiti Trichogramma cacoeciae March. (Hym.: Trichogrammatidae)'nin yaprak büken türlerinde (Lep.: Tortricidae) doğal etkinliği üzerinde araştırmalar, 341-354s". Türkiye 4. Biyolojik Mücadele Kongresi, 26-29 Ocak 1999, Adana, 633 s.

Özgür AF, Kütük M 2003. Adana ili meyve sinekleri (Tephritidae: Diptera) faunasının tespiti. Çukurova Üniversitesi Ziraat Fakültesi Dergisi, 18(2): 35-44.

Pakyürek B 2006. Gazi Üniversitesi Zooloji Müzesindeki Tephritidae (Diptera) Familyası Örneklerinin Değerlendirilmesi. Gazi Üniversitesi Fen Bilimleri Enstitüsü, Yüksek Lisans Tezi, Biyoloji Ana Bilim Dalı, Ankara, 431 pp.

Papp L 1994. Család: Fúrólegyek - Tephritidae (Trypetidae). In: Jermy T. and Balázs K., (eds.) A növényvédelmi állattan kézikönyve, 5: 94-117pp.

Richter VA 1970. 62. Tephritidae (Trypetidae). Keys to the insects of the European part of the USSR. Opred Faune SSSR, 103: 132-172.

Séguy E 1930. Contribution à l'étude des Diptères du Maroc. Mémoire de la Société des Sciences Naturelles et Physique du Maroc, 24: 1-206.

Séguy E 1934. Contribution à la connaissance des insectes diptères du Maroc, Notes scientifiques.Terre et Vie, 4: 161-162.

Séguy E 1941. Dipteres recueillis par M. Berland dans le Sud Marocain. Annales de la Société Entomologique de France, 110: 1-23.

Séguy E 1949. Dipteres de Sud-Marocain (Vallée du 
Draa) recueillis par M L Berland en 1947. Revue française d'Entomologie, 16: 152-161.

Séguy E 1953. Diptères du Maroc. Encyclopédie Entomologique (B) II. Diptera, 11: 77-92.

Smith JJ, Bush GL 1999. "Phylogeny of the subtribe Carpomyina (Trypetinae), emphasizing relationships of the genus Rhagoletis 187-217pp". In: Fruit flies (Tephritidae): Phylogeny and evolution of behavior (Ed: Aluja, M., Norrbom, A. L.). CRC Press, London, 984pp.

Stalažs A, Balalaikins M 2017. Country checklist of Rhagoletis Loew (Diptera: Tephritidae) for Europe, with focus on $R$. batava and its recent range expansion. Proceedings of the Latvian Academy of Sciences. Section B, 71(3): 103-110.

Surányi D, Haltrich A 2006. Insects Influencing the Production of Rose Hips. 52. Növényvédelmi Tudományos Napok, Budapest, 91 pp.

Thompson F 1998. Fruit fly expert identification system and systematic information database. Myia, 9: $1-224$.
Tuba K 2009. Adatok három gyümölcslégyfaj Vas megyei előfordulásához. Növényvédelem, 45: 491495.

Ulu O, Önuçar A, Zümreoğlu A, Uzun S, Erdügen TM, Aykaç K, Kılıç M, Çakır O, Ceylan S, Koçlu T 1995. Kiraz Bahçelerinde Entegre Mücadele Araştırma, Geliştirme ve Uygulama Projesi, BKA / U17, 1. Dilim sonuç raporu, 1-84 pp.

Ulusoy MR, Vatansever G, Uygun N 1999. The cherry pests, their natural enemies and observations on some important species in Ulukıșla (Niğde) and Pozantı (Adana) province of Turkey. Turkish Journal of Entomology, 23(2): 111-120.

White IM, Elson-Harris MM 1992. Fruit Flies of Economic Significance: Their Identification and Bionomics. CAB International and ACIAR, London, 601pp.

Yaran M, Kütük M 2016. Fruit flies (Diptera: Tephritidae) fauna in Nevşehir and Niğde provinces with a new record from Turkey. Turkish Journal of Zoology, 40(5): 785-800. 